\title{
INCLUSION IN THE CLASSROOM: EXAMINING FEELINGS OF INCLUSION OF NEWCOMER AND ABORIGINAL STUDENTS IN ONTARIO'S PUBLIC SCHOOL SYSTEM
}

\author{
By \\ Rachel Lobel, BA (Hons.), Memorial University of Newfoundland, 2010
}

Presented to Ryerson University

in partial fulfillment of the requirements for the degree of

\author{
Master of Arts \\ in the Program of \\ Immigration and Settlement Studies
}

Toronto, Ontario, Canada, 2011

() Rachel Lobel 2011 


\section{Author's Declaration}

I hereby declare that I am the sole author of this major research paper.

I authorize Ryerson University to lend this paper to other institutions or individuals for the purpose of scholarly research.

I further authorize Ryerson University to reproduce this paper by photocopying or by other means, in total or in part, at the request of other institutions or individuals for the purpose of scholarly research. 


\title{
INCLUSION IN THE CLASSROOM: EXAMINING FEELINGS OF INCLUSION OF NEWCOMER AND ABORIGINAL STUDENTS IN ONTARIO'S PUBLIC SCHOOL SYSTEM
}

\author{
Rachel Lobel \\ Master of Arts, 2011 \\ Immigration and Settlement Studies \\ Ryerson University
}

\begin{abstract}
Although schools have the potential to be inclusive spaces for children and youth from all backgrounds, the current study has found that in Ontario, newcomer and Aboriginal students' perceptions of inclusion differ from those of their non-newcomer and nonAboriginal counterparts. Through the analysis of a survey conducted in 2009 of students enrolled in public, private or Catholic schools from grades 6 through 12, this essay compares the feelings of inclusion of newcomer and Aboriginal students in Ontario to those not falling within these two categories. Further, it determines whether or not the feelings of inclusion exhibited by the respondents in Ontario were similar to or different from those of their counterparts in the rest of the provinces. Interestingly, though newcomers in Ontario were actually found to feel more included in their schools than their non-newcomer counterparts, this was not the case in the rest of Canada, but, while Aboriginal students felt less included than their non-Aboriginal counterparts in all provinces, in Ontario the gap between the two groups was wider. This essay examines these findings and makes suggestions for improving inclusivity in Ontario's school system.
\end{abstract}

Key words: social inclusion; social exclusion; schools; newcomer children and youth; Aboriginal children and youth; colonialism 


\section{Acknowledgments}

I would like to extend a warm thank you to my supervisor, Anver Salooojee, for his constant support and advisement and as well to my second reader, Francis Hare for his thoughtful comments and encouragement. I would also like to thank all my friends and family for being patient and understanding but especially my parents, Alison and Paul Lobel, and my grandmother, Goldie Lobel, as I would not have been able to do this without them. 


\section{Table of Contents}

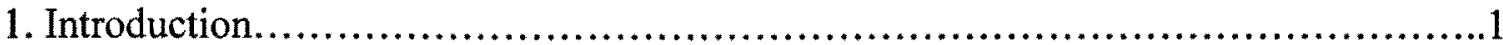

2. Theoretical Framework

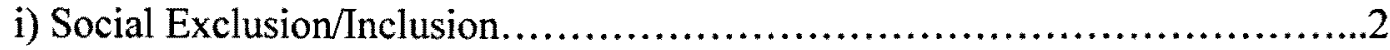

3. Context

ii) Social Inclusion in Schools.................................................

i) Canada as a Settler Nation......................................................

ii) The Oppression of Aboriginal Peoples..........................................6

iii) Canada as a Multicultural Nation.........................................

4. Previous Research

i) Newcomers in Canadian Classrooms...........................................9

ii) Aboriginals in Canadian Classrooms.........................................11

iii) Predictors of Self-Esteem...................................................12

5. Method

iv) Contribution of the Current Research.......................................15

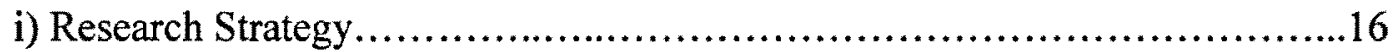

ii) Data Set.................................................................

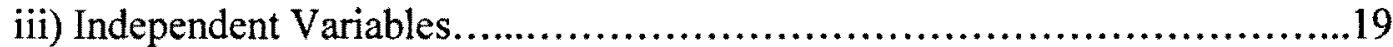

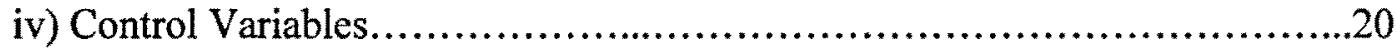

6. Results

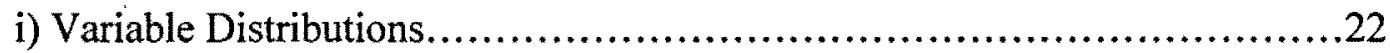

ii) Models A, B and C: Respondents in Ontario................................26

iii) Models D, E and F: Respondents not in Ontario.............................31

7. Discussion

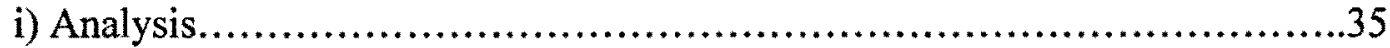

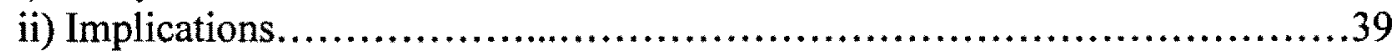

iii) Policy Recommendations.............................................41

iv) Areas for Further Research.............................................44

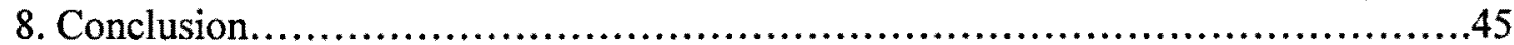

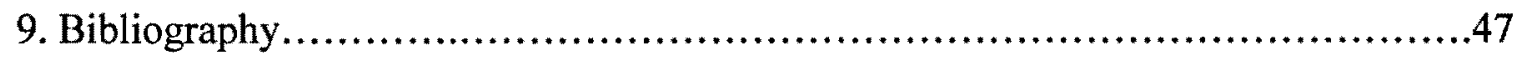

\section{List of Tables}

Table 1: Variable Distributions of Newcomer Variable, Weighted.....................24

Table 2: Variable Distributions of Aboriginal Variable, Weighted......................25

Table 3: Variable Distributions for Respondents in Ontario, Weighted...................28

Table 4: Models of Respondents in Ontario, Weighted.................................30

Table 5: Variable Distributions for Respondents not in Ontario, Weighted................33

Table 6: Models of Respondents not in Ontario, Weighted...............................34 


\section{Introduction}

Although schools have the potential to be inclusive spaces for children and youth from all backgrounds, the current study has found that in Ontario, newcomer and Aboriginal students' perceptions of inclusion differ from those of their non-newcomer and non-Aboriginal counterparts. Through the analysis of a survey conducted in 2009 of students enrolled in public, private or Catholic schools from grades 6 through 12, this essay compares the feelings of inclusion of newcomer and Aboriginal students in Ontario to those not falling within these two categories. Further, the study determines whether or not the feelings of inclusion exhibited by the respondents in Ontario were similar to or different from those of their counterparts in the other provinces in Canada. Interestingly, though newcomers in Ontario were actually found to feel more included in their schools than their non-newcomer counterparts, this was not the case in the rest of Canada, but, while Aboriginal students felt less included than their non-Aboriginal counterparts in all provinces, in Ontario the gap between the two groups was wider. Hence, while Ontario may indeed be succeeding in welcoming newcomers into the school system, the same cannot be said for the Aboriginal population. This essay begins by explaining the social inclusion/social exclusion theory through which this research is framed. It then positions both immigrants and Aboriginals in Canadian society by providing a brief overview of Canada's colonial past, the process by which Aboriginals were oppressed and the implementation of the Multiculturalism policy that exists today. It then introduces the previous research that has been conducted on the school experiences of newcomers and Aboriginals in Canadian schools, predictors of self-esteem and as well the present study's intention to contribute to this literature. This is then followed by an explication of the 
methods and data set used, a discussion of the variables included and a description of the results. And finally, the findings are analyzed, implications are explored and suggestions and areas for further research are given.

\section{Theoretical Framework}

\section{i) Social Exclusion/Social Inclusion}

The term social exclusion became popular in international literature during the 1970s and 1980s due to a growing discontent with the function of the concept of poverty. While poverty failed to capture inequality related to such things as mental or physical disabilities, long-term unemployment and the inadequacy of the welfare state, exclusion could better represent the process by which marginalization occurred by considering such elements. According to British sociologist Peter Townsend, by replacing poverty with exclusion, the issue becomes not just about subsistence or lack thereof but about the ability of individuals to participate in normal everyday activities. Further, exclusion better explains the process of disadvantage, its evolution and the historical marginalization of groups of people as a relationship between individuals and society (Hunter \& Jordan, 2010).

According to the Laidlaw Foundation, social exclusion can become a major threat to social cohesion and economic prosperity of society as a whole (Laidlaw Foundation, 2002). Social inclusion on the other hand, although not the opposite of exclusion, is both a process and a goal that attempts to respond to exclusion. It is about "making sure that all children and adults are able to participate as valued, respected and contributing members of society" (Laidlaw Foundation, 2002). It is about recognizing the shared 
aspirations of people and about closing "physical, social and economic distances separating people rather than only eliminating barriers" (Laidlaw Foundation, 2002). Community and social agencies now use the framework to promote social justice and ensure that attention is being paid to the rights of society's most vulnerable, and governments use it to reorient policy, service delivery and political intervention (Wotherspoon, 2002).

\section{ii) Social Inclusion in Schools}

The term inclusion in the context of schooling took off in the early 1980 s as a framework for thinking about students with physical, learning or developmental disabilities. In the mid-1990s, the conversation began to incorporate a wider notion of inclusion in schooling by opening dialogue about social diversity more generally, workplace learning, adult education and citizenship education. Recent scholarship has argued that "schools are inclusive insofar as they are public spaces in which children and youth from diverse backgrounds are expected to have access to common services, curricula and experiences that, in turn, are linked to prospects for their eventual participation and inclusion in other social and economic venues" (Wotherspoon, 2002, p. 1). Yet, despite the fact that schools have become decidedly more inclusive in their mandate, "schooling is also infused (both internally and in its relations with wider social structures and policy frameworks) with tensions and conflicts that have potential to generate new or continuing forms of exclusion" (Wotherspoon, 2002, p. 2). For example, when an individual enters the school system with a specific disadvantage that contributes to their lack of success or socialization into the school environment, consequences of this 
experience may lead to low academic achievement or a failure to graduate which will in turn perpetuate the individual's exclusion later in life. As newcomer and Aboriginal children and youth are more likely to face additional stress in Canadian schools than their non-newcomer, non-Aboriginal counterparts and thus are more likely to experience exclusion, school systems and researchers need to pay close attention to their progress. And as individuals' perception of their own personal experiences can have a huge effect on their performance and outcomes, measuring self-reported feelings of inclusion is infinitely important to the current climate (Veland, Midthassel \& Idsoe, 2009).

\section{Context}

\section{i) Canada as a Settler Nation}

The country Canada as it is known today was created through colonization by two then imperial powers: Britain and France (Buckner, 1993). Although, from the point of first contact in 1497 to 1867 when Ontario, Quebec, New Brunswick and Nova Scotia entered into a federal union, population growth was slow, two main waves of immigration gave the territory the base it needed to become a country (Buckner, 1993; Kelley \& Trebilcock, 1998). The first of these was an influx of American loyalist refugees who sought protection after the American Revolution and the second was the result of depressed economic conditions in Britain and displacement from technological change that acted as major push factors for thousands to seek resettlement in Canada (Kelley \& Trebilcock, 1998). Once British North America was formed in 1867, which led to a governing body that adopted the strengthening and expansion of the area as a national policy, immigration became more of a goal from within rather than solely the 
result of external factors. Attracting newcomers developed into a tool for economic prosperity, a method of Western expansion and a partner of the railway construction (Kelley \& Trebilcock, 1998). And though many settlers were lost to the United States, colonization was realized, forming the country we have today.

Despite this apparent need for population growth, life for new immigrants in Canada was seldom easy, particularly if you were not of British ancestry. Discrimination was rampant in the nascent country, even in times of economic prosperity (Hoerder, 2006). Prospective immigrants were either desirable or undesirable dependent largely on ethnicity, but as Canada's neighbour to the south was a more attractive destination, particularly for agriculturalists, Canada was forced to accept more people from the undesirable category in order to fill the vast territory to the west (Buckner, 1993; Kelley \& Trebilcock, 1998; Ramirez, 2009). This led to an intensely hierarchical society where white, British males were dominant, other Europeans followed and those from Asia or Africa who were allowed to settle came in at a distant last. Discrimination was also enacted against those with either a mental or physical disability, those who were not heterosexual and women who proved themselves to be of "lesser character" by for example, having a child out of wedlock. While this exclusion was omnipresent in Canada's earlier years as a country, several particular instances are more famously remembered. The Chinese head tax, the internment and forced deportations of Germans, Italians and the Japanese during the Second World War and Canada's failure to protect Jewish refugees during the Holocaust are some of the most notable illustrations of this racist legacy though they are certainly not the only examples (Kelley \& Trebilcock, 1998). 


\section{ii) The Oppression of Aboriginal Peoples}

Like all settler nations, Canada's history is also stained by its oppression and severe mistreatment of its indigenous peoples. Once immigrants began outnumbering the Aboriginals, they began asserting that the Aboriginals were all simple savages and attempting to assimilate them. This consequently led to the destruction of their economic, social and governmental structures (Green, 1997). In 1871, the newly formed Canadian government began negotiating treaties with bandleaders that relegated indigenous people to small, often infertile, pieces of land called reserves, while they claimed the rest of the land as their own. Most bandleaders did not know they were in fact signing over the land but understood that they were signing peace treaties. These reserves were and are still today devastating places to live with a lack of educational and employment opportunities, poor housing and inadequate health services (Friesen \& Friesen, 2002).

To further its policy of assimilation, Canada also used education as a means of cultural genocide. By the beginning of the 1900 s, residential schools were the norm for Indians and attendance was compulsory. This school system denied Aboriginal parents any involvement in their children's education by forcefully taking them out of their homes and isolating them from their communities (Green, 1997; Carr-Stewart, 2006). In the schools, they were not allowed to speak their native language, were indoctrinated with Euro-Canadian ideologies and physically and emotionally abused. Further, they were not provided with a proper education but were taught how to become manual laborers. The legacy of these experiences in Aboriginal communities is family and community breakdowns, alcoholism, suicides, mental, physical and sexual abuse and overrepresentation in prisons (Green, 1997; Friesen \& Friesen, 2002). 


\section{iii) Canada as a Multicultural Nation}

Despite its history, Canada today prides itself on being one of the only countries to uphold multiculturalism as an official policy (Lund, 2003; Lund, 2006). The policy, which came into being in 1971, recognizes that all Canadian men and women should have equal rights, freedoms and responsibilities whatever their background or beliefs and attempts to promote intercultural understanding in order to eliminate racism and discrimination (Gill \& Chalmers, 2001; Hammett \& Bainbridge, 2009; Bromley, 2011). Although this policy is often celebrated, it is also heavily criticized for giving the impression that Canada has always believed in equality and acceptance and does not have a history of oppression (Tan \& Smith Lefebvre, 2010). This leads to a situation where institutional discrimination is not properly confronted and thus not properly corrected.

While the government has in recent years begun recognizing certain aspects of its history that are considered unacceptable in the current context by issuing apologies and compensation to those who suffered, it has clearly not yet come to terms with its past of colonialism. Shortly after publicly apologizing to the victims of the residential school system in June of 2008, Prime Minister Steven Harper blatantly announced at a press conference for the G20 summit in Pittsburgh:

We are one of the most stable regimes in history. There are very few countries that can say for nearly 150 years they've had the same political system without any social breakdown, political upheaval or invasion. We are unique in that regard. We also have no history of colonialism (Henderson \& Wakeham, 2009, p. 1). 
Needless to say, this separation between the comments and the apology were duly pointed out by the Aboriginal community and is highly symbolic to those still awaiting a decolonized society.

Unfortunately both the government and society at large have remained largely in denial of the full extent of Canada's past and recent scholarship has identified education as playing a key role in the perpetuation of this ignorance as it fails to reveal the truth about injustices experienced by both Aboriginals and newcomers who were considered racially or ethnically inferior. Further, they fail to recognize the Eurocentric tendencies within the institution of education itself that privilege white students with European ancestry at the expense of newcomers and Aboriginals (Godlewska, Moore \& Bednasek, 2010). Consequently, understanding and exposing the experiences of these two groups in the current education system is both necessary and urgent for supplying proof that changes are needed. Though residential schools no longer exist, their legacy lives on as the source of Aboriginal people's current alienation from the school system. As a direct result of both residential schools and the systemic discrimination Aboriginal people have experienced throughout Canada's history, their average socioeconomic status is far below that of non-Aboriginal Canadians. And it is this coupled with Canada's current failure to decolonize that creates a public school system that reinforces, perpetuates and strengthens exclusion amongst Aboriginal people. The following section will discuss previous research that has been conducted on the school experiences of both newcomer and Aboriginal children in the Canadian context and will also propose how the current research contributes to the said area of study. 


\section{Previous Research}

\section{i) Newcomers in Canadian Classrooms}

The literature that documents the experiences of newcomer children in Canadian classrooms is foremost qualitative research. Generally, there is a consensus that the experiences of newcomer children and youth in the classroom differ from those of nativeborn, dominant culture students and approaches to how these differences are explained can be grouped into two camps. The first group of academics documents unfavourable feelings resulting from structural issues within educational systems and the second attributes the negative experiences of these children and youth to the hardship associated with migration itself as well as the process of acculturation.

Of the first group, Hutchinson (2009) uses the social psychologist Claude Steele's theory of the "stereotype threat" to describe how newcomers may experience anxiety in the classroom due to stereotyping by the dominant group. The explanation holds that it is similar to ordinary anxiety whereby "people who are conscious of their tense social situation may become distracted, experience an increase in body temperature, and suffer diminished performance levels" (Hutchinson, 2009, p.10) and consequently "underperform in a manner consistent with preconceived stereotypes; a kind of selffulfilling prophecy" (Hutchinson, 2009, p.10). Loneliness is also delineated as a feeling experienced by immigrant students in the classroom. Due to an inability to be accepted by their peers they become "empty of happiness," (Kirova, 2001, p.2), feel unwanted and disliked and undergo a loss of self-esteem (Kirova, 2001; Altinyelken, 2009). Further, it has been found that racial and ethnic minority students feel they are viewed unfavourably and discriminated against by their teachers (Peguero \& Bondy, 2010). In these cases, it 
can be seen as the fault of the school for not ensuring both staff members and students are taught to see through an anti-racist lens to thereby prevent the negative reception of newcomers.

Viewing the negative experiences of newcomers in schools as being due to migration and acculturative stress, according to Kirova (2001), is the traditional way in which English language learners and racially different students were viewed in education journals, as "at risk." This approach, however, is still seen in several recent articles (Gonzales-Ramos \& Saches-Nester, 2001; Goodwin, 2002; Von Worde, 2003; Bankston \& Zhou, 2006; Chen \& Chi-Hang Tse, 2010). Bankston and Zhou (2006) attribute the negative experiences of Asian newcomer children in schools to "high levels of parental authoritarianism and low levels of expectation and encouragement" (p.391), the difference in roles of American and Asian youth, their different cultural styles and the cultural gap between their new world and that of their families. Goodwin (2002) emphasizes these children's sense of dislocation and cultural disorientation while Chen and Chi-Hang Tse (2010) theorize that the performance of ethnic minority children depends largely on how they "react to challenges, behave according to social norms, and obtain acceptance in the peer group" (p.330). This, however, is not an ideal way to explain negative experiences of newcomer children and youth as it places blame on the personal issues of the children rather than on educational institutions at large. While it is important to consider stress caused by migration and acculturation when developing strategies to create inclusive classrooms, it should not be the focus as it essentializes newcomer children as vulnerable problems that need to be dealt with rather than new and unique resources that can contribute to a more dynamic and mutli-layered classroom. 
Further, by blaming victims, systemic and structural issues are missed and need for change becomes invisible.

\section{ii) Aboriginals in Canadian Classrooms}

Despite the importance of this topic, there has been relatively little research completed on the school experiences of Aboriginal children and youth, especially those of Aboriginals living off reserves. Previous research that has been conducted on these experiences has been primarily quantitative and has examined what affects educational attainment and learning of Aboriginal students. Though this research is limited in that it does not wholly explain the experience of these students, it is valuable in that it strongly agrees that Aboriginal students have consistently lower levels of educational attainment compared with their non-Aboriginal counterparts and as well suggests variables that can affect these levels. These variables can be categorized into three groups: parental, school and community characteristics.

Parental characteristics that have been found to be important to Aboriginal educational success are usually those relating to socioeconomic status, which is known to affect educational attainment in general (Perry \& McConney, 2010). For Aboriginal students, having a parent who has not graduated from high school, having a low family income and being raised by a lone parent have all been determined as negatively correlated with learning experiences of First Nations, Metis and Inuit children (Guevremont, 2010a; Guevremont, 2010b; Guevremont, 2010c). School quality has also been found to impact Aboriginal success as well as number of Aboriginals in a school and level of interaction with the dominant population (Spence, White \& Maxim, 2007; 
Richards, Vining \& Weimar, 2010). Contrary to the theory that designates minorities as more at risk (Hutchinson, 2009), a greater proportion of Aboriginals in a school leads to a situation where teaching staff expect less from students and efforts to engage classrooms are dulled, while a smaller proportion of Aboriginals forces the minority group to integrate and consequently build cultural capital (Richards, Vining \& Weimar, 2010).

Finally, predictors relating to community characteristics are also identified in the literature as important for understanding the achievement of Aboriginal children and youth - those in metropolitan areas do better than those away from urban centres and those in communities with low socioeconomic development and lack of occupational diversity often achieve less. This is because further distance from economic prospects leads to lowered motivation while little need for a wide variety of employments in a community provides no demand for a competitive education system (Spence, White $\&$ Maxim, 2007). These factors are all crucial contributors to the processes of social exclusion as well as important in understanding why Aboriginal children and youth feel less included as a group than non-Aboriginals as they are far more likely to disadvantaged in these ways.

\section{iii) Predictors of Self-Esteem}

As most of the literature that documents feelings of inclusion or general experiences of children and youth in schools is of a qualitative nature and does not overtly demarcate specific characteristics that need to be controlled for when analyzing large samples, quantitative research on self-esteem was also relied on to determine which variables ought to be controlled for in the present models. Self-esteem, or one's self- 
concept, is thought to be complex and affected by many factors and also to be closely related to feelings of inclusion (Nutbrown \& Clough, 2009). Low levels are associated with increased levels of depression, suicide ideation, eating disorders, antisocial behavior, gang membership and teen pregnancy as well as less ability to cope and adapt in challenging situations (Rumbaugh Whitesell, Mitchell, Kaufman, Spicer and the Voices of the Indian Teens Project Team, 2006; Hammond, Watson, O'Leary \& Cothran, 2009). Some of the major factors that can affect self-esteem levels of school-aged individuals are sex, age, birth order, parenting style and socioeconomic status.

Concerning sex, boys often score higher on self-esteem tests than do girls (Israel \& Ivanova, 2002; Rousseaux, Drapeau, Lacroix, Bagillshya \& Heusch, 2005; Lawrence, 2006; Heaven \& Ciarrochi, 2008; Moksnes, Moljord, Espnes \& Byrne, 2010). This is generally explained by the idea that males and females tend to place emphasis on different competencies; boys view themselves more in terms of their physical and academic achievements while girls are more concerned with being socially competent (Israel \& Ivanoca, 2002; Lawrence, 2006). These differences can also become exaggerated with the onset of adolescence. During this period, girls experience higher levels of stress than do boys and generally are more vulnerable to psychological and emotional problems such as anxiety or depression (Moksnes, Moljord, Espnes \& Byrne, 2010), however, levels of self-esteem in both girls and boys are thought to decline during this stage (Heaven \& Ciarrochi, 2008).

Though the evidence diverges in trends, there is generally a consensus that birth order and parenting style can also influence the self-esteem of children and youth (Shebloski, Conger \& Widaman, 2005; Lawrence, 2006). Some studies suggest that older 
siblings tend to be favoured by their parents and consequently score higher on selfesteem tests (Gates, Lineberger, Crockett \& Hubbard, 1988) while some suggest that the same occurs for the later born (Shebloski, Conger \& Widaman, 2005). This dynamic is then further complicated by the influences of socioeconomic status on parenting style. Middle-class parents have been shown to have on average a more authoritative approach to parenting and achieve closer relationships with their children, while lower-class parents may have to work more and consequently have less time for childrearing (Falci, 2011). Further, low socioeconomic status can also cause children to have less opportunities for activities and hobbies that can promote friendships and social networks (Davies, Davis, Cook \& Waters, 2008) and suffer from less preferential treatment from teachers due to their tendency to be less academically oriented (Veland, Midthassel \& Idsoe, 2009).

Ethnicity and Aboriginality have also been shown to have repercussions for children and youth in self-esteem tests. Though little work has been done on Aboriginal children and youth in Canada living off of reserves, Aboriginals in the United States have yielded lower levels of self-esteem than non-Aboriginals (Richards, Vining \& Weimar, 2010). On the other hand, though the relationship between ethnicity and self-esteem has been explored, it has been relatively inconclusive. Only Asian children and youth have somewhat consistently exhibited self-esteem levels lower than other ethnicities and this is often explained by the supposed Eastern culture of collectivity (Bankston \& Zhou, 2006). 


\section{iv) Contribution of the Current Research}

Although the present research is fairly general, it contributes to what is already known in several very important ways. Firstly, in terms of the literature on newcomer school experiences, most of the research thus far has approached the topic qualitatively. For this reason, most of the studies available are focused on either particular locations or ethnic groups and, further, do not compare their experiences with those of the native-born population. While the current research does not yield results as descriptive as those produced using qualitative methods, it does have the advantage of providing a larger picture of newcomer students' school experiences. Further, by contrasting newcomer students with non-newcomers, it allows us to judge how the two groups differ and whether or not negative school experiences are unique to newcomers, as previous literature has suggested.

Although previous research on the school experiences of Aboriginal students is most often quantitative, it has almost solely focused on educational attainment. And while understanding what causes Aboriginal students to achieve less than their nonAboriginal counterparts is extremely important, the present study expands on our knowledge by adding a new dimension. It has been noted previously that feeling included in a school affects educational attainment and thus tackling exclusion of Aboriginals in the school system is consequently an imperative aspect of a holistic solution. Further, as this particular study does not include students in Aboriginal-run schools or those residing in the territories, it provides a clear picture of the students who attend schools where Aboriginals themselves share less power and allows for a more focused interpretation. 
Finally, this research is also valuable as it contributes to an emerging trend in scholarship that sees similarities in newcomer and Aboriginal communities in terms of marginalization and historical experiences. According to whiteness theory, which understands white people to be institutionally privileged in society, both Aboriginals and non-white newcomers share a common history as colonized people. Further, the Canadian government has a long history of viewing both immigrants and Indians as foreign groups that needed to be brought into the mainstream and henceforth implemented similar programs to attempt to assimilate them (Bohaker \& Iacovetta, 2009). This does not mean that Aboriginals and newcomers necessarily identify with each other in day-to-day life (De Finney, 2010), however, there have recently been moves by social justice activists that advocate on behalf of these two groups to join in solidarity. No One is Illegal, an organization whose main concern is for migrant rights, has recognized the need to support Canada's indigenous people by bringing together Aboriginal activists and also understands the importance of forming allegiance with all groups dedicated to promoting anti-racism (Wright, 2003). Acknowledging the potential commonalities between the experiences of newcomer and Aboriginal young people, this study attempted to determine whether or not the two groups were similar in the way they answered questions that denoted feelings of inclusion.

\section{Method}

\section{i) Research Strategy}

The goal of the present study was to predict whether or not newcomer and Aboriginal students feel as included in Ontario's schools as their non-newcomer, non- 
Aboriginal counterparts, and also whether the situation in Ontario is similar to or different from that in the rest of the provinces. According to theory, an inclusive school is one in which all students can connect to its environment, culture and organization (Baskin, 2002). Based on these definitions, three items were chosen to measure feelings of inclusivity. In all three, respondents were asked, "How strongly do you agree with the following statement?" and could respond with either "strongly agree", "agree", "disagree" or "strongly disagree". The statements were as follows: "I feel I am part of my school"; "The teachers at my school treat me fairly"; and "I feel close to people at my school". All three items were chosen as they have been outlined in the literature as necessary for inclusion (Baskin, 2002; Omidvar \& Richmond, 2003; Beutel, 2010; Murray, 2011) and as well are feelings that are evidently important for students' wellbeing.

To address the research problem, binary logistic regression models were run to determine how students answered these three questions dependent on whether they were an Aboriginal, a newcomer or neither. For each item, dummy variables were created that grouped "strongly agree" with "agree" and "disagree" with "strongly disagree." The tests were conducted twice for each item, the first time including only those students who were in Ontario and the second, including all those not in Ontario. The results were then analyzed for differences among the groups.

\section{ii) Data Set}

The data set utilized in the present study was actually not intended for the purposes of predicting feelings of inclusion of newcomer and Aboriginal children and 
youth but was designed to further knowledge of psychosocial correlates of smoking. Entitled the Youth Smoking Survey 2008-2009 and conducted by the Special Surveys Division of Statistics Canada, the sample $(\mathrm{N}=51922)$ is Canadian students from grades 6 to 12 that attend private, public or Catholic schools. Excluded from the survey were all those living in the Yukon, Nunavut and the North-West Territories as well as those in institutions, those on First Nations reserves and those who attend special schools (e.g. schools for the hearing impaired). Schools were chosen through random sampling within each province and interviews took place in a class period (Statistics Canada, 2010).

This data set was chosen for the present study primarily due to an interest in the three items chosen as predictors of feelings of inclusion but also for reasons related to its scope. Most importantly, the survey asked respondents for their Aboriginal status which allowed for a comparison between Aboriginals and non-Aboriginals, and as well asked how many years the respondents had been in Canada. In addition, it only surveyed those in public, private or Catholic schools which permitted an analysis of only those not on reserves. It must be noted, however, that there were variables absent from the data that would also have been valuable for the analysis conducted. Above all, variables to indicate levels of socioeconomic status would have been important to include as controls as it is known that Aboriginal populations are generally worse off than non-Aboriginals in terms of income and education, are more often single parents and tend to migrate more because of these barriers (Green, 1997). Thus, without these variables the predictive power of the Aboriginal variable is lessened due to disproportionate levels of socioeconomic status that exist within it when compared to the variable representing non-Aboriginals. Further, variables pertaining to the school's characteristics and quality would also have been 
important for controls as well as to explore the school effects of inclusion. Without such variables, I attempted to control for influences using items related to family and school smoking prevalence, however, as the relationship between smoking and socioeconomic status is complex (McCann, 2010), results were analyzed with caution.

\section{iii) Independent Variables}

The main independent variables of interest were number of years the respondent had been living in Canada and whether or not the respondent is an Aboriginal person. For the newcomer variable, a dummy variable was created to separate respondents who had been in Canada for 0 to 2 years from those who had been in Canada 3 or more years, thus, for the purposes of this study, the term 'newcomer' is not synonymous with 'immigrant' but is intended to signify those who are very new to Canada. I decided to choose those in Canada for 0 to 2 years as opposed to all those not born in Canada or even those in Canada 0 to 5 years as it is known that newcomer children often have quicker rates of acculturation than their adult counterparts (Telzer, 2011), which means those in Canada 3 years or more are likely to have achieved some degree of integration.

For the question "Are you an Aboriginal person?" respondents could give the interviewer four possible answers: "No, I am not an Aboriginal person", "Yes, Inuit", "Yes, First Nations" or "Yes, Metis". I decided to group all three "Yes" answers as one category - "Aboriginal Person" - as the sample sizes of the individual groups were not large enough to yield statistically significant results, but also for the purposes of providing a general idea of the Aboriginal person's experience in public schools as opposed to more detailed information. 


\section{iv) Control Variables}

Using previous literature that documents both Aboriginals and newcomers in Canadian classrooms as well as past research on the predictors of self-esteem, three sets of variables were selected to include in the present models as controls. The first grouping is intended to capture variation due to sociodemographic differences and consists of sex, grade, language spoken at home and birth order. In each case, dummy variables were created with the exception of grade, which was left as continuous (6-12). For sex, options were "Male" or "Female", for language spoken at home, the categories were "English", "French" or "Other" and possible answers for birth order were "Only", "Youngest", "Middle" or "Oldest".

As there is very limited information in the data set to account for the socioeconomic status of the respondents, certain variables were chosen to act as indicators. These variables were whether or not they had a parent or guardian who smoked, whether or not they had a sibling who smoked and how many individuals smoked in their house excluding them. The number of individuals who smoked in their house remained continuous while parent or guardian that smoked and sibling that smoked were transformed into dummy variables. The choice to include these items as indicators was due to previous research that has overwhelmingly linked socioeconomic status with smoking (Kendzor, Businelle, Mazas, Cofta-Woerpel, Reitzel, Vidrine, Li, Costello, Cinciripini \& Ahluwalia, 2009; Stringhini, Sabia, Skipley, Brunner, Nabi, Kirimaki \& Singh-Manoux, 2010; Reitzel, Businelle, Kendzor, Li, Cao, Castro, Mazas, CoftaWoerpel, Cinciripini \& Wetter, 2010; McCann, 2010). It has been found that, while smoking prevalence is declining, this is less so for those with low socioeconomic status 
(McCann, 2010) and smoking can be especially high among those who have little hope for future security and opportunities (Kendzdor et al., 2009). It is understood, however, that smoking prevalence is of course complex and there are many other predictors of smoking apart from socioeconomic status and thus, these variables are only intended as indicators and this lack of ability to fully control for socioeconomic status is considered in the analysis. For both parent or guardian who smokes and sibling who smokes, dummy variables were created and options were simply "yes" or "no" and for the number of people who smoke in the house, the variable was left as continuous.

The final group of controls chosen was for school quality indicators. These items were the number of students that smoked on school property and the percentage of people that smoked in the respondent's grade. For the variable representing number of students that smoked on school property, dummy variables were created that grouped "none" with "a few" and "some" with "a lot". As the item that asked about the percentage of people that smoked in the respondent's grade was given in categories such as " $0 \%$ to $10 \%$," these values were recoded to the midpoint and employed in the model as a continuous variable. Again these variables were chosen because of previous literature that connects prevalence of smoking with school quality (Henderon, Ecob, Wright \& Abraham, 2008; Sabiston, Lovato, Ahmed, Pullman, Hadd, Campbell, Mykforuk \& Brown, 2009) as more inclusivity and quality in relationships between teachers and students are both negatively correlated with smoking rates. However, it should again be noted that these variables are serving as mere indicators due to an absence of more definitive variables in the data set. 


\section{Results}

\section{i) Variable Distributions}

When comparing the newcomer category in terms of those who answered " $0-2$ years" in Canada and those who answered " 3 or more years" as well as those in or not in Ontario within these two groups, there are a few differences worth noting (see Table 1 for a full summary). Firstly, when observing what language was spoken at home, not surprisingly, those in the " $0-2$ years" category were far more likely than the " 3 or more years" group to speak an "other" language at home (in Ontario, "0-2 years" $-74.1 \%$ and "3 or more years" - $11.3 \%$; not in Ontario, " $0-2$ years" $-59.0 \%$ and " 3 or more years" $6.4 \%$ ). However, what is interesting to note is that respondents not in Ontario had a very similar chance of speaking French at home regardless of whether they were a newcomer or not, $20.3 \%$ and $25.6 \%$ respectively. This is likely due to the fact that Quebec has its own system for receiving immigrants that favours newcomers from francophone countries in order to preserve and fortify the use of French in the province (Ghosh, 2004), and as Quebec receives among the most migrants in the country, this consequently raises the percentage of French-speaking newcomers not in Ontario.

Other inconsistencies in distribution that resided within the newcomer category were small differences in some of the categories related to smoking. The chance of those in the "0-2 years" category having a parent or guardian or a sibling who smoked was slightly less than for those in the " 3 or more years" group, however, the former reported having slightly higher percentages of people who smoked in their grade. Though these inconsistencies are small, it is possible they are due to the fact that, while many of Canada's newcomers are highly educated, they are more likely to live in poverty than the 
larger population (Fleury, 2007). This leads to a situation where education serves as a protective factor for smoking within the family but poverty forces them to live in lowerclass neighbourhoods and consequently attend schools of lesser quality (Beiser, Hou, Hyman \& Tousignant, 2002).

In terms of differences between the Aboriginal and non-Aboriginal categories, as was expected, distribution was most skewed in the "socioeconomic indicators" and "school quality indicators" sections both for those in and not in Ontario (see Table 2 for a full summary). While $59.7 \%$ of Aboriginals in Ontario had a parent or guardian who smoked and $36.6 \%$ had a sibling who smoked, the numbers for non-Aboriginals in Ontario were $38.8 \%$ and $14.8 \%$ respectively. Similarly, $66.7 \%$ of Aboriginals not in Ontario had a parent or guardian who smoked and $41.7 \%$ a sibling who smoked compared to only $43.5 \%$ and $20.7 \%$ respectively of non-Aboriginals not in Ontario. Further, the number of people who smoked in the home was for Aboriginal respondents more than double that for non-Aboriginal respondents both in and not in Ontario.

Although not as obvious as differences in socioeconomic indicators, variation in school quality indicators revealed that Aboriginal respondents were again below nonAboriginal respondents in this category, especially for those in Ontario. Ontario's Aboriginal respondents indicated that "some" or "a lot" of individuals smoked on school property $56.8 \%$ of the time while only $43.6 \%$ of non-Aboriginal in the province answered the same way. Further, the average percentage of people who smoked in their grade indicated by Aboriginals in Ontario was $39.2 \%$ compared to only $27.1 \%$ by nonAboriginals. For those not in Ontario, the average percentages indicated were $35.9 \%$ and $29.4 \%$ respectively. 
Table 1: Variable Distributions of Newcomer Variable, Weighted

\begin{tabular}{|c|c|c|c|c|}
\hline & \multicolumn{2}{|c|}{$\begin{array}{c}3 \text { or more years } \\
N=48473\end{array}$} & \multicolumn{2}{|c|}{$\begin{array}{c}0 \text { to } 2 \text { years } \\
N=1858\end{array}$} \\
\hline & $\begin{array}{c}\text { Ontario } \\
\mathrm{N}=19629 \\
\end{array}$ & $\begin{array}{c}\text { Not in } \\
\text { Ontario } \\
\mathrm{N}=28844\end{array}$ & $\begin{array}{l}\text { Ontario } \\
\mathrm{N}=1020 \\
\end{array}$ & $\begin{array}{c}\text { Not in } \\
\text { Ontario } \\
N=839\end{array}$ \\
\hline \multicolumn{5}{|l|}{ Aboriginal Person } \\
\hline No & $95.8 \%$ & $90.2 \%$ & $95.5 \%$ & $86.8 \%$ \\
\hline Yes & $4.2 \%$ & $9.8 \%$ & $4.5 \%$ & $13.2 \%$ \\
\hline \multicolumn{5}{|l|}{ Sex } \\
\hline Female & $49.0 \%$ & $49.4 \%$ & $36.8 \%$ & $50.2 \%$ \\
\hline Male & $51.0 \%$ & $50.6 \%$ & $63.2 \%$ & $49.8 \%$ \\
\hline Grade (6-12) (mean) & 9.14 & 8.94 & 9.59 & 9.06 \\
\hline \multicolumn{5}{|c|}{ Language spoken at home } \\
\hline English & $87.1 \%$ & $68.0 \%$ & $22.2 \%$ & $20.7 \%$ \\
\hline French & $1.6 \%$ & $25.6 \%$ & $3.7 \%$ & $20.3 \%$ \\
\hline Other & $11.3 \%$ & $6.4 \%$ & $74.1 \%$ & $59.0 \%$ \\
\hline \multicolumn{5}{|l|}{ Birth Order } \\
\hline Only & $26.2 \%$ & $22.1 \%$ & $30.9 \%$ & $23.8 \%$ \\
\hline Youngest & $28.5 \%$ & $32.1 \%$ & $22.7 \%$ & $24.5 \%$ \\
\hline Middle & $13.5 \%$ & $15.4 \%=$ & $13.4 \%$ & $14.6 \%$ \\
\hline Oldest & $31.7 \%$ & $30.4 \%$ & $33.0 \%$ & $37.0 \%$ \\
\hline \multicolumn{5}{|c|}{ Socioeconomic indicators: } \\
\hline \multicolumn{5}{|c|}{ Parent or guardian who smokes } \\
\hline No & $60.1 \%$ & $54.1 \%$ & $62.4 \%$ & $57.6 \%$ \\
\hline Yes & $39.9 \%$ & $45.9 \%$ & $37.6 \%$ & $42.4 \%$ \\
\hline \multicolumn{5}{|l|}{ Sibling who smokes } \\
\hline No & $84.3 \%$ & $77.3 \%$ & $89.4 \%$ & $84.7 \%$ \\
\hline Yes & $15.7 \%$ & $22.7 \%$ & $10.6 \%$ & $15.3 \%$ \\
\hline \multicolumn{5}{|c|}{$\begin{array}{l}\text { Number of people who smoke in } \\
\text { house excluding respondent }\end{array}$} \\
\hline (mean) & .27 & .45 & .33 & .48 \\
\hline \multicolumn{5}{|c|}{ School quality indicators: } \\
\hline \multicolumn{5}{|c|}{$\begin{array}{l}\text { Individuals that smoke on school } \\
\text { property }\end{array}$} \\
\hline None or few & $56.7 \%$ & $51.6 \%$ & $45.3 \%$ & $57.3 \%$ \\
\hline Some or a lot & $43.3 \%$ & $48.4 \%$ & $54.7 \%$ & $42.7 \%$ \\
\hline
\end{tabular}


Table 2: Variable Distributions of Aboriginal Variable, Weighted

\begin{tabular}{|c|c|c|c|c|}
\hline & \multicolumn{2}{|c|}{$\begin{array}{c}\text { Not an Aboriginal } \\
\mathrm{N}=46855\end{array}$} & \multicolumn{2}{|c|}{$\begin{array}{l}\text { Aboriginal } \\
N=3855\end{array}$} \\
\hline & $\begin{array}{c}\text { Ontario } \\
\mathrm{N}=19840\end{array}$ & $\begin{array}{c}\text { Not in } \\
\text { Ontario } \\
\mathrm{N}=27015\end{array}$ & $\begin{array}{l}\text { Ontario } \\
\mathrm{N}=879\end{array}$ & $\begin{array}{c}\text { Not in } \\
\text { Ontario } \\
N=2975\end{array}$ \\
\hline \multicolumn{5}{|l|}{ Years in Canada } \\
\hline 3 or more & $95.3 \%$ & $97.4 \%$ & $94.9 \%$ & $96.4 \%$ \\
\hline $0-2$ & $4.7 \%$ & $2.6 \%$ & $5.1 \%$ & $3.6 \%$ \\
\hline \multicolumn{5}{|l|}{ Sex } \\
\hline Female & $48.4 \%$ & $49.2 \%$ & $45.4 \%$ & $48.6 \%$ \\
\hline Male & $51.6 \%$ & $50.8 \%$ & $54.6 \%$ & $51.4 \%$ \\
\hline Grade (6-12) (mean) & 9.18 & 8.97 & 9.39 & 9.04 \\
\hline \multicolumn{5}{|c|}{ Language spoken at home } \\
\hline English & $83.9 \%$ & $64.9 \%$ & $87.0 \%$ & $84.6 \%$ \\
\hline French & $1.6 \%$ & $27.0 \%$ & $4.1 \%$ & $10.4 \%$ \\
\hline Other & $14.4 \%$ & $8.0 \%$ & $8.9 \%$ & $5.0 \%$ \\
\hline \multicolumn{5}{|l|}{ Birth Order } \\
\hline Only & $26.6 \%$ & $22.2 \%$ & $25.9 \%$ & $21.0 \%$ \\
\hline Youngest & $28.4 \%$ & $32.0 \%$ & $25.9 \%$ & $32.1 \%$ \\
\hline Middle & $13.3 \%$ & $15.0 \%$ & $14.6 \%$ & $18.5 \%$ \\
\hline Oldest & $31.7 \%$ & $30.8 \%$ & $33.6 \%$ & $28.3 \%$ \\
\hline
\end{tabular}

Socioeconomic indicators:

Parent or guardian who smokes

$\begin{array}{lllll}\text { No } & 61.2 \% & 56.5 \% & 40.3 \% & 33.3 \% \\ \text { Yes } & 38.8 \% & 43.5 \% & 59.7 \% & 66.7 \%\end{array}$

Sibling who smokes

No

$85.2 \%$

$79.3 \%$

$63.4 \%$

$58.3 \%$

Yes

$14.8 \%$

$20.7 \%$

$36.6 \%$

$41.7 \%$

Number of people who smoke in house excluding respondent (mean) 


\section{School quality indicators:}

Individuals that smoke on school property

None or few

Some or a lot

Percentage of people that smoke in grade (mean)
$56.4 \%$

$43.6 \%$

$27.1 \%$
$51.6 \%$

$48.4 \%$

$29.4 \%$
$43.2 \%$

$56.8 \%$

$50.0 \%$

$50.0 \%$

\section{ii) Models A, B and C: Respondents in Ontario}

Due to evidence in the literature that the experiences of newcomer and minority students in Canadian classrooms tend to be generally negative in nature, it was expected that respondents in Canada only 0 to 2 years would disagree with the three statements used to predict feelings of inclusion more often than those in Canada 3 or more years. According to the present study, newcomer children and youth in the province of Ontario feel more included in their schools than their non-newcomer counterparts (for variable summaries see Table 3; for models see Table 4). For the survey item "I feel I am part of my school", those in Canada for 0 to 2 years had an odds ratio of agreeing $180.4 \%$ more than those in Canada 3 or more years, for the question "The teachers at my school treat me fairly", they had an odds ratio of agreeing $150.8 \%$ more and even for "I feel close to people at my school" they had an odds ratio of agreeing $35.2 \%$ more. For Aboriginal students, the results were consistent with previous research on Aboriginals' school experiences as for all three items they disagreed more often than their non-Aboriginal counterparts. They had an odds ratio of agreeing $54.7 \%$ less for the item "I feel I am part of my school", for "The teachers at my school treat me fairly" they had an odds ratio of 
agreeing $27.2 \%$ less than non-Aboriginal respondents and for the last item, "I feel I am close to people at my school", the odds ratio that Aboriginals agreed was 53.6\% less than non-Aboriginals.

For the other socio-demographic variables, results were, for the most part, as expected. Males tended to agree less to all statements than their female counterparts, presumably due to their tendency to place more value on individualistic accomplishments than do females (Israel \& Ivanova, 2002). For the grade variable, the odds ratio of agreeing went down with increased grade for the items, "I feel I am part of my school" and "I feel close to people at my school", although it went up for the question "The teachers at my school treat me fairly". This is not surprising as getting older means maturation which might lead to a stronger connection with teachers yet also brings on the period of adolescence which might consequently lead individuals to place more emphasis on aspects of life outside of school (Arslan, 2009). In the category that controlled for birth order, although there were two instances where results were not statistically significant and the results as a whole did not reveal stark patterns, the findings generally indicated that those who are not "only" children feel included in their schools more than those who have siblings, which again is a logical outcome. Only children often have less opportunity to socialize with other children and might feel less connected to the school's environment than those who have siblings who attend the same school or those with more developed social skills obtained through contact with siblings in childhood. The only variable amongst those of a sociodemographic nature that yielded more surprising results was the "language spoken at home" category, as all findings but one were insignificant. This was in fact unexpected because it has been indicated in the literature that the school 
experiences of language minorities can be negative (Welpy, 2010). However, as this variable - language spoken at home - does not represent the English language skills of the respondents, both the "French" and the "other" categories might encompass a wide variety of skill levels including some individuals who speak English as if they were native speakers and thus are not a language minority within the school itself.

For both socioeconomic and school quality indicators, results were again as expected. The literature indicates that those with lower socioeconomic status and those who attend schools of poorer quality tend to feel less included in their schools (Henderon, Ecob, Wright \& Abraham, 2008; Sabiston et al., 2009). Despite the fact that a few of the results were not statistically significant, this research was generally reinforced.

\section{Table 3: Variable Distributions for Respondents in Ontario, Weighted}

\begin{tabular}{|c|c|c|c|c|c|c|}
\hline \multirow[t]{2}{*}{$\begin{array}{l}\text { Respondents in } \\
\text { Ontario }\end{array}$} & \multicolumn{2}{|c|}{$\begin{array}{l}\text { I feel I am part } \\
\text { of my school, } \\
N=20763\end{array}$} & \multicolumn{2}{|c|}{$\begin{array}{l}\text { The teachers at my } \\
\text { school treat me fairly, } \\
\qquad N=20703\end{array}$} & \multicolumn{2}{|c|}{$\begin{array}{l}\text { I feel close to people } \\
\text { at my school, } \\
N=20749\end{array}$} \\
\hline & Agree & Disagree & Agree & Disagree & Agree & Disagree \\
\hline Years in Canada & & & & & & \\
\hline 3 or more & $84.0 \%$ & $16.0 \%$ & $85.8 \%$ & $14.2 \%$ & $83.6 \%$ & $16.4 \%$ \\
\hline $0-2$ & $88.3 \%$ & $11.7 \%$ & $93.6 \%$ & $6.4 \%$ & $77.3 \%$ & $22.7 \%$ \\
\hline $\begin{array}{l}\text { Self-reported } \\
\text { Aboriginal status }\end{array}$ & & & & & & \\
\hline $\begin{array}{l}\text { Not an Aboriginal } \\
\text { person }\end{array}$ & $84.8 \%$ & $15.2 \%$ & $86.4 \%$ & $13.6 \%$ & $84.0 \%$ & $16.0 \%$ \\
\hline Aboriginal person & $71.0 \%$ & $29.0 \%$ & $76.8 \%$ & $23.2 \%$ & $71.4 \%$ & $28.6 \%$ \\
\hline Sex & & & & & & \\
\hline Female & $85.5 \%$ & $14.5 \%$ & $88.6 \%$ & $11.4 \%$ & $83.5 \%$ & $16.5 \%$ \\
\hline Male & $83.1 \%$ & $16.9 \%$ & $83.7 \%$ & $16.3 \%$ & $83.4 \%$ & $16.6 \%$ \\
\hline Grade (6-12)(mean) & 9.05 & 9.68 & 9.18 & 8.99 & 9.07 & 9.58 \\
\hline
\end{tabular}


Language spoken at home

$\begin{array}{lllllll}\text { English } & 84.0 \% & 16.0 \% & 85.8 \% & 14.2 \% & 84.1 \% & 15.9 \% \\ \text { French } & 84.7 \% & 15.3 \% & 86.4 \% & 13.6 \% & 76.6 \% & 23.4 \% \\ \text { Other } & 85.7 \% & 14.3 \% & 88.4 \% & 11.6 \% & 79.9 \% & 20.1 \%\end{array}$

\section{Birth Order}

Only

Youngest

$83.6 \% \quad 16.4 \%$

$83.4 \%$

$16.6 \%$

$86.1 \%$

$13.9 \%$

$85.3 \%$

$14.7 \%$

$82.2 \%$

$17.8 \%$

$86.6 \%$

$13.4 \%$

$83.6 \%$

$16.4 \%$

$83.4 \%$

$16.6 \%$

Oldest

$84.8 \%$

$87.8 \%$

$12.2 \%$

$83.2 \%$

$16.8 \%$

$15.2 \%$

$84.6 \%$

$15.4 \%$

\section{Socioeconomic}

\section{indicators:}

Parent or guardian who smokes

$\begin{array}{lllllll}\text { No } & 87.4 \% & 12.6 \% & 88.1 \% & 11.9 \% & 84.8 \% & 15.2 \% \\ \text { Yes } & 79.7 \% & 20.3 \% & 83.7 \% & 16.3 \% & 81.6 \% & 18.4 \%\end{array}$

Sibling who smokes

No

$86.3 \% \quad 13.7 \%$

$87.9 \%$

$21.6 \%$

$80.6 \%$

$12.1 \%$

$19.4 \%$

$85.1 \%$

$79.7 \%$

$14.9 \%$

$78.4 \%$

Number of people who smoke in house

excluding respondent

.24

.43

.24

.44

.25

.36

\section{School quality indicators:}

Individuals that smoke on school property

None or few

$87.3 \%$

$12.7 \%$

$87.5 \%$

$12.5 \%$

$86.2 \%$

$13.8 \%$

Some or a lot

$80.4 \%$

$19.6 \%$

$84.3 \%$

$15.7 \%$

$80.1 \%$

$19.9 \%$

Percentage of people

that smoke in grade

$25.8 \%$

$35.1 \%$

$26.6 \%$

$31.8 \%$

$25.9 \%$

$34.9 \%$ 
Table 4: Models of Respondents in Ontario, Weighted

\begin{tabular}{|c|c|c|c|c|c|c|}
\hline \multirow{2}{*}{$\begin{array}{l}\text { Models A, B \& C: } \\
\text { Respondents in } \\
\text { Ontario } \\
\end{array}$} & \multicolumn{2}{|c|}{$\begin{array}{l}\text { A. I feel I am part } \\
\text { of my school, } \\
\mathrm{N}=20763 \\
\text { Nagelkerke } \\
\text { Rsquare }=.056\end{array}$} & \multicolumn{2}{|c|}{$\begin{array}{l}\text { B. The teachers at my } \\
\text { school treat me fairly, } \\
\mathrm{N}=20703 \\
\text { Nagelkerke } \\
\text { Rsquare }=.064\end{array}$} & \multicolumn{2}{|c|}{$\begin{array}{c}\text { C. I feel close to } \\
\text { people at my school, } \\
\mathrm{N}=20749 \\
\text { Nagelkerke } \\
\text { Rsquare }=.030\end{array}$} \\
\hline & $\begin{array}{l}\text { Odds } \\
\text { Ratio }\end{array}$ & $\begin{array}{c}\text { Standard } \\
\text { Error }\end{array}$ & $\begin{array}{l}\text { Odds } \\
\text { Ratio }\end{array}$ & $\begin{array}{l}\text { Standard } \\
\text { Error }\end{array}$ & $\begin{array}{l}\text { Odds } \\
\text { Ratio }\end{array}$ & $\begin{array}{c}\text { Standard } \\
\text { Error }\end{array}$ \\
\hline $\begin{array}{l}\text { Years in Canada } \\
3 \text { or more } \\
0-2\end{array}$ & $2.804^{* * *}$ & .173 & $2.508 * * *$ & .213 & $1.352^{*}$ & .132 \\
\hline $\begin{array}{l}\text { Self-reported } \\
\text { Aboriginal status } \\
\text { Not an Aboriginal } \\
\text { person } \\
\text { Aboriginal person }\end{array}$ & $.453 * * *$ & .100 & $.728^{*}$ & .114 & $.464^{* * *}$ & .101 \\
\hline $\begin{array}{l}\text { Sex } \\
\text { Female } \\
\text { Male }\end{array}$ & $.745^{* * *}$ & .052 & $.728 * * *$ & .055 & .924 & .051 \\
\hline Grade (6-12) & $.907^{* * *}$ & .022 & $1.159 * * *$ & .023 & $.936 * * *$ & .021 \\
\hline $\begin{array}{l}\text { Language spoken at } \\
\text { home } \\
\text { English } \\
\text { French } \\
\text { Other }\end{array}$ & $\begin{array}{l}1.249 \\
.834\end{array}$ & $\begin{array}{l}.196 \\
.094\end{array}$ & $\begin{array}{l}.789 \\
1.141\end{array}$ & $\begin{array}{l}.194 \\
.100\end{array}$ & $\begin{array}{c}.808 \\
.659 * * *\end{array}$ & $\begin{array}{l}.168 \\
.085\end{array}$ \\
\hline $\begin{array}{l}\text { Birth Order } \\
\text { Only } \\
\text { Youngest } \\
\text { Middle } \\
\text { Oldest }\end{array}$ & $\begin{array}{c}1.062 \\
1.394^{* * *} \\
1.187^{*}\end{array}$ & $\begin{array}{l}.069 \\
.089 \\
.067\end{array}$ & $\begin{array}{c}.976 \\
.835^{*} \\
1.161^{*}\end{array}$ & $\begin{array}{l}.075 \\
.087 \\
.075\end{array}$ & $\begin{array}{c}1.205^{* *} \\
1.275^{* *} \\
1.387^{* * *}\end{array}$ & $\begin{array}{l}.068 \\
.084 \\
.065\end{array}$ \\
\hline $\begin{array}{l}\text { Socioeconomic } \\
\text { indicators: }\end{array}$ & & & & & & \\
\hline $\begin{array}{l}\text { Parent or guardian } \\
\text { who smokes } \\
\text { No } \\
\text { Yes }\end{array}$ & $.838 * *$ & .056 & .918 & .060 & $.909^{*}$ & .056 \\
\hline $\begin{array}{l}\text { Sibling who smokes } \\
\text { No } \\
\text { Yes }\end{array}$ & .911 & .068 & $.693 * * *$ & .072 & .920 & .069 \\
\hline
\end{tabular}


Number of people

who smoke in house

excluding

respondent

$.839^{* *}$

.032

$.914^{*}$

.035

$.922 *$

.034

School quality

indicators:

Individuals that

smoke on school

property

None or few

Some or a lot

$.824 * * * \quad .056$

.914

.062

$.906^{*}$

.056

Percentage of people

that smoke in grade

$.995^{* * *} \quad .00$

001

$.988^{* * *} \quad .001$

$.993^{* * *}$

.001

Constant

$18.613^{* * *}$

.239

$2.787^{* * *}$

.249

$11.508^{* * *}$

.228

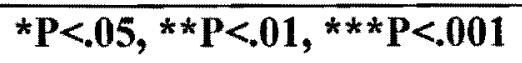

\section{iii) Models D, E and F: Respondents not in Ontario}

Unlike the results for students in Ontario, the newcomer variable in the models that only included respondents not in Ontario yielded findings more in agreement with previous research although slightly more optimistic (for variable summaries, see Table 5; for models, see Table 6). Those in Canada for 0 to 2 years had an odds ratio of agreeing to the statement "I feel I am part of my school" $25.2 \%$ less than those in Canada 3 or more years and for the survey item "I feel close to people at my school", their odds ratio was $10.4 \%$ less. However, for the question "The teachers at my school treat me fairly", the odds ratio that newcomers agreed was, like respondents in Ontario, higher than their non-newcomer peers by $28.6 \%$. For the Aboriginal variable, the results for respondents not in Ontario again agreed with the literature, however, not as strongly as the results for students not in Ontario. Aboriginal respondents had an odds ratio of agreeing to the statement "I feel I am part of my school" $17.5 \%$ less than their non-Aboriginal peers, for 
the statement "The teachers at my school treat me fairly", their odds ratio of agreeing was just $8.6 \%$ less and for the item, "I feel close to people at my school", it was $30.7 \%$ less than their non-Aboriginal counterparts.

The remaining control variables acted quite similarly to those of the respondents in Ontario. Notable differences only occurred in the "Language spoken at home" variable and in the pattern by which numbers were statistically significant. Those who indicated that the language they spoke at home was French had an odds ratio of agreeing to both the statements "I feel I am part of my school" and "The teachers at my school treat me fairly" higher than those who spoke English at home while the rest of the results for this category were insignificant. As most people who speak French at home reside in Quebec, this may indicate that schools are more inclusive for French-speaking Quebecois than for English students in the rest of the provinces, however, it is not possible to give a definite explanation due to the complexity of the issue and the general nature of these particular data. The other difference was in the patterns by which results were statistically significant. Unlike the models that included only those respondents in Ontario, all findings were statistically significant for the socioeconomic and school quality indicators, however they were almost all insignificant in the "Birth order" category. Again, the results for the socioeconomic and school quality indicators reinforced previous findings as lower levels of each produced less agreement to the three statements intended to represent feelings of inclusion. 
Table 5: Variable Distributions for Respondents not in Ontario, Weighted

\begin{tabular}{|c|c|c|c|c|c|c|}
\hline \multirow[t]{2}{*}{$\begin{array}{l}\text { Respondents not in } \\
\text { Ontario }\end{array}$} & \multicolumn{2}{|c|}{$\begin{array}{l}\text { I feel I am part } \\
\text { of my school, } \\
N=30010\end{array}$} & \multicolumn{2}{|c|}{$\begin{array}{c}\text { The teachers at my } \\
\text { school treat me fairly, } \\
N=29915\end{array}$} & \multicolumn{2}{|c|}{$\begin{array}{l}\text { I feel close to people } \\
\text { at my school, } \\
\mathrm{N}=29955\end{array}$} \\
\hline & Agree & Disagree & Agree & Disagree & Agree & Disagree \\
\hline \multicolumn{7}{|l|}{ Years in Canada } \\
\hline 3 or more & $83.6 \%$ & $16.4 \%$ & $82.7 \%$ & $17.3 \%$ & $83.6 \%$ & $16.6 \%$ \\
\hline $0-2$ & $77.2 \%$ & $22.8 \%$ & $85.1 \%$ & $14.9 \%$ & $76.6 \%$ & $23.4 \%$ \\
\hline \multicolumn{7}{|l|}{ Self-reported } \\
\hline \multicolumn{7}{|l|}{ Aboriginal status } \\
\hline $\begin{array}{l}\text { Not an Aboriginal } \\
\text { person }\end{array}$ & $84.2 \%$ & $15.8 \%$ & $83.4 \%$ & $16.6 \%$ & $84.0 \%$ & $16.0 \%$ \\
\hline Aboriginal person & $76.7 \%$ & $23.3 \%$ & $76.5 \%$ & $23.5 \%$ & $76.5 \%$ & $23.5 \%$ \\
\hline \multicolumn{7}{|l|}{ Sex } \\
\hline Female & $84.7 \%$ & $15.3 \%$ & $85.4 \%$ & $14.6 \%$ & $83.2 \%$ & $16.8 \%$ \\
\hline Male & $82.2 \%$ & $17.8 \%$ & $80.1 \%$ & $19.9 \%$ & $83.3 \%$ & $16.7 \%$ \\
\hline Grade (6-12) & 8.89 & 9.27 & 8.98 & 8.84 & 8.91 & 9.17 \\
\hline \multicolumn{7}{|l|}{$\begin{array}{l}\text { Language spoken at } \\
\text { home }\end{array}$} \\
\hline English & $83.3 \%$ & $16.7 \%$ & $83.1 \%$ & $16.9 \%$ & $83.6 \%$ & $16.4 \%$ \\
\hline French & $84.6 \%$ & $15.4 \%$ & $82.6 \%$ & $17.4 \%$ & $83.1 \%$ & $16.9 \%$ \\
\hline Other & $82.2 \%$ & $17.8 \%$ & $81.9 \%$ & $18.1 \%$ & $81.0 \%$ & $19.0 \%$ \\
\hline \multicolumn{7}{|l|}{ Birth Order } \\
\hline Only & $84.2 \%$ & $15.8 \%$ & $83.9 \%$ & $16.1 \%$ & $83.3 \%$ & $16.7 \%$ \\
\hline Youngest & $83.1 \%$ & $16.9 \%$ & $80.2 \%$ & $19.8 \%$ & $83.3 \%$ & $16.7 \%$ \\
\hline Middle & $83.0 \%$ & $17.0 \%$ & $82.2 \%$ & $17.8 \%$ & $83.0 \%$ & $17.0 \%$ \\
\hline Oldest & $83.9 \%$ & $16.1 \%$ & $85.2 \%$ & $14.8 \%$ & $83.5 \%$ & $16.5 \%$ \\
\hline
\end{tabular}

Socioeconomic

indicators:

Parent or guardian who smokes

$\begin{array}{lllllll}\text { No } & 86.2 \% & 13.8 \% & 86.1 \% & 13.9 \% & 85.9 \% & 14.1 \% \\ \text { Yes } & 80.6 \% & 19.4 \% & 79.3 \% & 20.7 \% & 80.4 \% & 19.6 \% \\ & & & & & & \\ \text { Sibling who smokes } & & & & & & \\ \text { No } & 85.6 \% & 14.4 \% & 84.9 \% & 15.1 \% & 84.7 \% & 15.3 \% \\ \text { Yes } & 78.1 \% & 21.9 \% & 76.9 \% & 23.1 \% & 79.4 \% & 20.6 \%\end{array}$


Number of people who smoke in house

excluding respondent

\section{School quality}

\section{indicators:}

Individuals that smoke on school property

None or few

$86.4 \%$

$13.6 \%$

$85.7 \%$

$79.5 \%$

$14.3 \%$

$85.6 \%$

$14.4 \%$

Some or a lot

$80.5 \%$

$19.5 \%$

$20.5 \%$

$80.7 \%$

$19.3 \%$

Percentage of people that smoke in grade

Table 6: Models of Respondents not in Ontario, Weighted

\begin{tabular}{|c|c|c|c|c|c|c|}
\hline $\begin{array}{l}\text { Models D, E \& F: } \\
\text { Respondents not in } \\
\text { Ontario }\end{array}$ & $\begin{array}{r}\text { D. I fee } \\
\text { of my } \\
\mathrm{N}= \\
\text { Nag } \\
\text { Rsqua }\end{array}$ & $\begin{array}{l}\text { am part } \\
\text { hool, } \\
010 \\
\text { erke } \\
=.068 \\
\end{array}$ & $\begin{array}{r}\text { E. The ter } \\
\text { school tre } \\
\mathrm{N}= \\
\text { Nag } \\
\text { Rsqua }\end{array}$ & $\begin{array}{l}\text { hers at my } \\
\text { me fairly, } \\
9915 \\
\text { kerke } \\
=.093\end{array}$ & $\begin{array}{r}\text { F.I fe } \\
\text { people a } \\
\mathrm{N}= \\
\mathrm{Nag} \\
\text { Rsqua }\end{array}$ & $\begin{array}{l}\text { lose to } \\
\text { y school, } \\
955 \\
\text { erke } \\
=.036\end{array}$ \\
\hline & $\begin{array}{l}\text { Odds } \\
\text { Ratio }\end{array}$ & $\begin{array}{c}\text { Standard } \\
\text { Error }\end{array}$ & $\begin{array}{l}\text { Odds } \\
\text { Ratio }\end{array}$ & $\begin{array}{c}\text { Standard } \\
\text { Error }\end{array}$ & $\begin{array}{l}\text { Odds } \\
\text { Ratio }\end{array}$ & $\begin{array}{c}\text { Standard } \\
\text { Error }\end{array}$ \\
\hline $\begin{array}{l}\text { Years in Canada } \\
3 \text { or more } \\
0-2\end{array}$ & $.748^{*}$ & .131 & $1.286^{*}$ & .132 & $.896^{*}$ & .67 \\
\hline $\begin{array}{l}\text { Self-reported } \\
\text { Aboriginal status } \\
\text { Not an Aboriginal } \\
\text { person } \\
\text { Aboriginal person }\end{array}$ & $.825 * *$ & .065 & $.914^{*}$ & .067 & $.693 * * *$ & .063 \\
\hline $\begin{array}{l}\text { Sex } \\
\quad \text { Female } \\
\text { Male }\end{array}$ & $.808^{* * *}$ & .043 & $.720^{* * *}$ & .043 & .939 & .042 \\
\hline Grade (6-12) & $.900 * * *$ & .014 & $1.214^{* * *}$ & .014 & $.923^{* * *}$ & .013 \\
\hline $\begin{array}{l}\text { Language spoken at } \\
\text { home } \\
\text { English } \\
\text { French } \\
\text { Other }\end{array}$ & $\begin{array}{c}1.157^{* *} \\
1.121\end{array}$ & $\begin{array}{l}.052 \\
.087\end{array}$ & $\begin{array}{c}1.237^{* * *} \\
.948\end{array}$ & $\begin{array}{l}.050 \\
.083\end{array}$ & $\begin{array}{l}.955 \\
.948\end{array}$ & $\begin{array}{l}.050 \\
.083\end{array}$ \\
\hline
\end{tabular}


Birth Order

Only

Youngest

.917

.063

$.785^{* * *}$

.063

.932

.062

Middle

.927

.073

.904

.986

.072

Oldest

.063

1.058

.971

.062

Socioeconomic

indicators:

Parent or guardian

who smokes

No

Yes

$.883^{* *}$

.048

$.879^{* *}$

.047

$.848^{* * *}$

.047

Sibling who smokes

No

Yes

$.774 * * *$

.052

$.793 * * *$

.052

$.906^{*}$

.052

Number of people

who smoke in house

excluding respondent

$.849 * * *$

.023

$.931 * *$

.023

$.885^{* * *}$

.023

\section{School quality}

indicators:

Individuals that

smoke on school

property

None or few

Some or a lot

$.904 *$

.046

$.728^{* * *}$

.047

$.865^{* * *}$

.045

Percentage of people

that smoke in grade

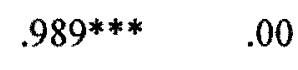

.001

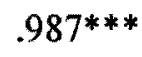

.001

$.994 * * *$

.001

Constant

$25.428 * * *$

.160

$2.462 * * *$

.156

$17.465^{* * *}$

.155

$* P<.05, * * P<.01, * * * P<.001$

\section{Discussion}

i) Analysis

Without considering the results of the models that examined those not in Ontario or the Aboriginal variable, the findings show that newcomers to Ontario feel more included in their schools than their non-newcomer counterparts. There are several 
arguments that can be put forth as to why this occurred. Firstly, Ontario is currently Canada's province that receives the most newcomers - according to Statistics Canada (2009), $52.3 \%$ of newcomers went to Ontario from 2001 to 2006 - which means that more often than not, they are not necessarily a minority. It is possible then that newcomers can immediately connect to their schools' environments by identifying with othet newcomers that attend. Further, as Ontario does receive the most newcomers, teathers and school administrators are naturally far more accustomed to welcoming these ińdividuals and have learned from experience how best to approach multicultural settings (Chan \& Ross, 2009). There is also academic research (Ghosh, 2004; Rezai-Rashti, 2008) that identifies Ontario as being ahead in terms of programs geared at settling newcomer children and youth as well as creating inclusivity within the classroom itself. Finally, it is also possible that newcomers simply overrated their feelings of inclusivity because they felt it was more desirable or because they were more self-conscious than those more accustomed to the school system. This final explanation, however, does not explain the substantial gap between the newcomer respondents in Ontario and those in the other provinces, as in all statements except "The teachers at my school treat me fairly" they had an odds ratio of agreeing less than their non-newcomer counterparts. And because in many of the provinces that have not traditionally received large numbers of newcomers school environments are not as conducive to welcoming these children and youth, the former explanations are more plausible.

Compared to the newcomer variable for respondents in Ontario, the results yielded in the Aboriginal category were quite dismal. Aboriginal students in Ontario that do not attend Aboriginal-run schools reportedly feel far less included in their schools than 
those who did not self-identify as Aboriginals. There are again several possible explanations for these results. An emerging trend in academic studies of children and youth has been to point out systemic issues within North American school systems that put Aboriginals at a disadvantage. This school of thought argues that Aboriginal people have alternative ways of knowing and teaching that have been passed down for generations and thus, because the way in which Aboriginal children and youth learn is ineffective in Canada's Eurocentric school system, they consequently do not connect to their schools' surroundings (Baskin, 2002; Friesen \& Friesen, 2002). Further, the teaching staff in Canada is composed of primarily white, heterosexual, middle-class females and thus Aboriginal students have difficulty identifying with their mentors and have trouble locating proper role models (Goodwin, 2002; Gomez, 2007; Kirova, 2008).

It has also been theorized that history and social studies courses do not adequately teach students about the oppression experienced by Canadian Aboriginal people which consequently alienates this population further (Joshee \& Bullard, 1992; Young \& Graham, 2000). When examining Ontario's secondary school curriculum, Godlewska, Moore and Bednasek (2010) found that, while curricular reforms have removed the worst expressions of racism in courses and textbooks, they have not addressed the "fundamental colonial attitudes in the mainstream curriculum" (p. 417). According to Godlewska, Moore and Bednasek (2010), this then perpetuates ignorance in Ontarian society and leaves most people oblivious to Canada's history of oppressing Aboriginals that has left them dispossessed for years. It has also been asserted that this ignorance of Canada's colonial past is both purposeful and strategic as it prevents society from challenging the institutionally generational inequity enforced on the Aboriginal 
population and permits the government to avoid properly confronting the complex and deep-seated barriers experienced by this population daily. Finally, it blinds the general society and encourages it to view Aboriginal people as second-class citizens and to blame them for their own misfortunes (Bruno-Jofre \& Henley, 2000).

Considering Ontario's ranking as the most advanced Canadian province in terms of pro-diversity teaching, it is surprising that the feelings of inclusivity of the Aboriginal population were so much lower than those of the non-Aboriginal respondents. And while socioeconomic status could not be properly controlled for, the findings still reveal grave institutional problems in Ontario generally. For example, why is it that newcomers felt far more included in their schools than non-newcomers and Aboriginals far less so than non-Aboriginal respondents? The immediate cause is perhaps the well-developed programs geared towards newcomers existing in Ontario, however, as I understand it, the answer lies more so in why these programs exist. It is because, while Ontario does have the highest concentration of Aboriginal people (CBC, 2010), the foreign born account for $27 \%$ of the province and as well, according to Citizenship and Immigration Canada (2005), are responsible for all of its net labour force growth. Consequently, the government understands that newcomers are more vital to the economy than are Aboriginal people, which detrimentally affects the attention and funds they receive. In recent years, there have actually been more moves, particularly by the Western provinces, to attempt to raise the academic standards of Aboriginal children and youth. The justification for these projects has been that, as the Aboriginal population is growing faster than the general population, they will be needed in Canada's future workforce. And while it is likely that Ontario will eventually embark down the same road, should it be 
that only those pertinent to the economy deserve the right to an enriching education? The answer of course is no, however, it has been the tradition for the Canadian government to act on behalf of the interest of the economy and this trend clearly still continues today. The current backlog of those awaiting family reunification stands at 140,000 meaning newcomers could wait up to 14 years to bring their parents to Canada (CBC News, 2011). Furthermore, in 2007 and 2008, for the first time in Canada's history, the country received more temporary foreign workers than immigrants, which demonstrates its commitment to attracting new workers as opposed to new citizens (Basen, 2011). Unfortunately, until the national agenda changes its attitude from economy-centered to people-centered, there may be few improvements made towards equity in the school system. The fact is that addressing the situation for Aboriginal children and youth in the school system means openly talking about the grave mistakes Canada made as a colonial country and sadly, importing workers is easier than reconciliation.

\section{ii) Implications}

According to Benick and Saloojee (1996), inclusion in the classroom involves fostering "the full personal, academic and professional development of all students" (p.

2). Through the current study that compared the answers to survey questions that indicated feelings of inclusion, it has been shown that newcomer and Aboriginal children both in Ontario and in the rest of the provinces exhibit these feelings at different levels which can lead one to assume that full development is not occurring for all students. The implications of these findings are two-fold. Most obviously, those individuals who are falling behind others in their connection with the school environment will no doubt be 
disadvantaged later in life. And while the Ministry of Education in Canada emphasizes the role of schooling as being vital for a "vibrant knowledge-based economy" (CMEC, 2008), it has been shown in academic research that students themselves view their education as an outlet where they can work towards a "good life" with worthwhile employment, a meaningful relationship, happiness and health (Zenkov, Harmon \& Van Lier, 2009). However, without equitable access to the education system's ability to provide these goals, those that face barriers will be far less likely to obtain them. In the current research, individuals who did not feel the connection between themselves and their school were concentrated in the Aboriginal group, a people who are severely disadvantaged in society in general. It is possible to argue that the present results are both a cause and an effect of this position - a cycle of exclusion - and it is only education itself that can interrupt this cycle.

The second major implication of exclusion in the school system is of a more general nature but of equal importance. As reported by educational historians, public schooling is a key social institution that has been used to create the society desired by the elite. Traditionally this was a Canadian polity that reflected British heritage, however, in the last thirty years this has changed in varying degrees to incorporate multiculturalism (Bruno-Jofre \& Henley, 2000). Whatever the goals, the point is that schools are microcosmic social spaces that teach young people how to exist in a society and thus if inequity persists, what can be expected of future generations? The fact is that whether or not overt racism is removed from curricula, if children grow up in environments where disadvantage is visible, it is inevitable that these adverse circumstances will be 
perpetuated. And if the status quo continues to be normalized, those who suffer will continue to be marginalized.

\section{iii) Policy Recommendations}

Although many recommendations have been made in the literature on how to promote social inclusion in the school setting, understanding that parliament will hold a Conservative majority with "economic recovery" as its driving force until at least 2015 (Gollom \& Davidson, 2011), I will focus on realistic solutions that do not directly involve the federal government. Firstly, and most basically, it is my understanding that the most powerful agents of change in the way in which schools operate are those who teach the teacher. This is, of course, because they have access to future educators during the most career-shaping time periods of their lives but also because they exist in a social space that encourages creativity, expression and criticism. Unfortunately, however, faculties of education have been shown to be inadequate concerning these matters as they are slow to digest the work of critical scholars. When examining the attitudes of education professors at a Canadian university, Ghosh and Tarrow (1993) found that only $60 \%$ of those surveyed dealt with issues of race, racism and ethnicity and only half of these individuals could actually specify how. In a more recent study conducted by Mujawariya (2007), 81 teacher candidates were surveyed to determine whether they felt they had been prepared to teach in diverse classrooms. The results showed that most felt they were not prepared to teach ethnically diverse classrooms, did not know how to address issues of racism, felt unprepared to adapt a lesson plan to address multicultural issues and felt uncertain about how to teach English language learners, and most responded that they did not feel the 
university was adequately meeting the needs of ethnic or cultural minorities in the classroom (Mujawariya, 2007). This, however, does not have to persist and slowly but surely, the proven need for inclusion in the classroom is being recognized. The problem is that it is not happening fast enough and is foremost being implemented in regions that are dependent on diverse peoples for their economy such as Toronto and Vancouver. Those academics whose expertise is in the forces of colonialism - the historical reasons for inequity and the institutional racism that is present in Canadian society - have an obligation to step further out of their niches and urgently share their work in locations and disciplines where these theories are traditionally not priorities in order to infiltrate this country's schools with teachers who understand these issues and conduct their classrooms accordingly.

A second important aspect that is contributing to this problem but has the potential to become a solution, is the relationship between Aboriginals and newcomers as well as all other marginalized groups such as the LBGT community, persons with a disability and racialized citizens in general. While there have been moves in recent years for those who advocate on behalf of migrants and Aboriginals to join in solidarity, there needs to be more rapport amongst these groups in day-to-day life. Both traditionally and contemporarily such groups have been institutionally disengaged from each other and this lack of interaction is sustained through Multiculturalism policy (De Finney, 2010). When interviewing 130 racialized girls from a less diverse city in British Columbia, De Finney (2010) found that, though these girls often felt separate from each other, their methods of negotiating their identities in a predominantly white society were very similar. Unfortunately, however, there is so little encouragement for relationship building 
between Aboriginals and newcomers that this connection is often left undiscovered and understanding of each "other" between these two groups is not being fully achieved. Yet the situation is not without hope, because there has been some recognition that this bond, as well as solidarity amongst other marginalized groups, means power in numbers (Wright, 2003) and there is no doubt that as these connections increase and mutual support continues, injustice and inequity will become less difficult to ignore.

A further suggestion that I would like to put forward is a strengthening of information-sharing of anti-racist teaching methods from the bottom up. According to Richards, Vining and Weimer (2010), some schools and districts have begun implementing culturally sensitive curricula and have subsequently attained above average levels of achievement amongst their Aboriginal students. The problem is that these curricula are not being implemented until a school reaches a particular threshold number of Aboriginal students to the point where some schools have begun inviting Aboriginal parents to send their children to them so that they can manage to reach this threshold (Richards, Vining \& Weimer, 2010). This again speaks to the trend by which programming is or is not enacted according to how it will affect the workforce. However, as programs that effectively reach out to Aboriginal students do exist as well as those for newcomer students, as demonstrated in Ontario, these methods can be spread if the teachers, students and parents already involved commit to sharing advice on best practices. Further, there is also a literature that documents the efficacy, successes and challenges of particular programs that have been implemented in Canadian school, although, the extent to which it reaches everyday teachers is questionable. Lund (2003) demonstrated in his work on teacher activists that those teachers who already promote 
social justice education do in some way use academic research in their work but admit that it is sometimes overly technical. Therefore there should be more effort by academics who research these topics to publish information in forms and sources that are more readily available. Curricula often contain many wildcards where teachers are given suggestions for how they can demonstrate or substantiate ideas but are permitted to develop their own method and it is in these instances where a teacher connected to a network of individuals who understand the need to be anti-racist and pro-diversity in their teaching can make a world of difference.

Finally and most importantly, it is time that Canadians begin engaging in meaningful conversations about the extent and severity of the residential school system. These schools served to oppress Canada's Aboriginal people right up until the 1980 s yet most Canadians are actually unaware that they even existed. Aboriginal individuals and communities cannot heal until their fellow Canadians understand the historical process that has led to and reinforces their exclusion. Locally, those who know the truth and are concerned with the fact Canadian society is generally oblivious to these issues, have the obligation to share their knowledge and educate their neighbours. Despite Prime Minister Steven Harper's claim that Canada has "no history of colonialism" (Henderson \& Wakeham, 2009, p. 1), injustice in this country is alive and well and it is through silence that it will continue.

\section{iv) Areas for Further Research}

Although this research was of a general nature, it is one of the few studies that compared aspects of school experiences of both newcomers and Aboriginal students with 
the general population. Yet due to the methods used and the lack of choice in the survey questions, there were many questions of detail that could not be answered in this particular project. Further research needs to be done to understand the impact of socioeconomic status on school experiences of Aboriginals as well as how Aboriginal children and youth understand the institution of school itself. Attention also needs to be paid to why newcomer students actually felt more included in their schools than nonnewcomers in Ontario and whether this occurred at the expense of native-born children, due to resentment of the native born or simply because their Canadian schools were better than those in their countries of origin. In terms of finding solutions to inequity in schools, understanding teacher networks that share best practices as well as existing relationships between newcomers and Aboriginals is pertinent to building awareness of their urgency and need for growth. Finally, more research needs to be conducted on all aspects of school experiences of Aboriginal children and youth across the country because education is the key to lifting them out of oppression and they receive far too little attention in academic thought.

\section{Conclusion}

The urgency of creating inclusive school environments for all students cannot be underestimated. Though Canada upholds a Multiculturalism policy, this does not mean that all its citizens are given equal opportunities in society and in life. Through exposing Canada's colonial past and demonstrating that its historical oppression of newcomers and Aboriginal people has consequences for today's school children, this paper hopes to contribute to the growing academic literature that concerns itself with these topics. The 
current government, like many governments before it, pays far too much attention to the country's economic well-being at the expense of human rights which leaves it up to others to advocate on behalf of marginalized peoples. If academics, teachers, students, parents, activists and non-activists commit to sharing strategies and information as well as amalgamating their causes, much difference can be made. Many Canadians are oblivious to the fact that there is a substantial portion of their history that the government purposely suppresses and until this past is exposed, recognized, accepted and acted upon, there will be little hope of justice both within schools and without. 


\section{Bibliography}

Altinyelken, Hulya Kosar. (2009). "Migration and Self-Esteem: Qualitative Study among Internal Migrant Girls in Turkey." Adolescence, 44(173): 149-163.

Arslan, Coskun. (2009). "Anger, Self-Esteem, and Perceived Social Support in Adolescence." Social Behavior and Adolescence, 37(4): 555-564.

Bankston III, Carl L. \& Min Zhou. (2006). "Being Well vs. Doing Well: Self-Esteem and School Performance among Immigrant and Non-Immigrant Racial and Ethnic Groups." International Migration Review, 36(2): 389-415.

Basen, Ira. (2011). "Temporary Foreign Workers: Why so Many all of a Sudden?" CBC News.

http://www.cbc.ca/news/politics/canadavotes2011/realitycheck/2011/04/temporar y-foreign-workers-why-so-many-all-of-a-sudden.html

Baskin, Cindy. (2002). "Re-Generating Knowledge: Inclusive Education and Research." Paper presented at the Annual Conference of the Canadian Indigenous and Native Studies Association. Toronto, Ontario.

Beiser, Morton, Feng Hou, llene Hyman \& Michel Tousignant. (2002). "Poverty, Family Process, and the Mental Health of Immigrant Children in Canada." American Journal of Public Health, 92(2): 220-227.

Benick, Gail \& Anver Saloojee. (1996). Creating Inclusive Post-Secondary Learning Environments. Toronto.

Beutel, Denise. (2010). “The Nature of Pedagogic Teacher-Student Interaction: A Phenomenographic Study." Australian Educational Researcher, 37(2): 77-91.

Bohaker, Heidi \& Franca Iacovetta. (2009). "Making Aboriginal People Immigrants too: A Comparison of Citizenship Programs for Newcomers and Indigenous Peoples in Post-War Canada, 1940s -1960s." Canadian Historical Review, 90(3): 427462.

Bromley, Patricia. (2011). "Multiculturalism and Human Rights in Civic Education: The Case of British Columbia, Canada." Educational Research, 53(2): 151-164.

Bruno-Jofre, Rosa \& Dick Henley. (2000). "Public Schooling in English Canada: Addressing Difference in the Context of Globalization." Canadian Ethnic Studies, $32(1): 38-43$.

Buckner, Phillip. (1993). "The Peopling of Canada." History Today, 43(11): 48-54. 
Carr-Stewart, Sheila. (2006). "The Changing Educational Governance of First Nations Schools in Canada: Towards Local Control and Educational Equity." Management in Education, 20(5): 6-12.

CBC News. (2010). "A Snapshot of Canada's Booming Aboriginal Population." http://www.cbc.ca/news/canada/story/2010/06/01/f-aboriginal-population.html

CBC News. (2011). "Overseas Parental Sponsorships Frozen, Fax Suggests: Government Source says Message Sent in Error." http://www.cbc.ca/m/rich/politics/story/2011/06/09/pol-immig-family-visafreeze.html

Citizenship and Immigration Canada. (2005). "Backgrounder." http://www.cic.gc.ca/english/department/media/backgrounders/2005/2005-1121.asp

Chan, Elaine \& Vicki Ross. (2009). "Examining Teachers' Knowledge on a Landscape of Theory, Practice and Policy." Curriculum and Teaching Dialogue, 11(1): 159171.

Chen, Xinyin \& Hennis Chi-Hang Tse. (2010). "Social and Psychological Adjustment of Chinese Canadian Children." International Journal of Behavioral Development, 34(4): 330-338.

CMEC. (2008). "Education in Canada." http://www.cmec.ca/pages/canadawide.aspx

Davies, B., E. Davis, K. Cook \& E. Waters. (2008). "Getting the Complete Picture:

Combining Parental and Child Data to Identify the Barriers to Social Inclusion for Children Living in Low Socioeconomic Areas." Child: Care, Health \& Development, 34(2): 214-222.

De Finney, Sandrina. (2010). “We Just Don't Know Each Other: Racialised Girls Mediate Multiculturalism in a Less Diverse City." Journal of Intercultural Studies, 31(5): 471-487.

Falci, Christina, D. (2011). "Self-Esteem and Mastery Trajectories in High School by Social Class and Gender." Social Science Research, 40(2): 586-601.

Fleury, Dominique. (2007). "A Study of Poverty and Working Poverty among Recent Immigrants." Human Resources and Social Development Canada.

Friesen, John W. \& Virginia Lyons Friesen. (2002). "Aboriginal Education: A Plea for Integration." Calgary: Detselig Enterprises. 
Gates, Larry, Mable Rowe Lineberger, Jeanine Crockett \& James Hubbard. (1988).

"Birth Order and its Relationship to Depression, Anxiety, and Self-Concept Test Scores in Children." Genetic Psychology, 149(1): 29-34.

Ghosh, Ratna. (2004). "Public Education and Multiculturalism Policy in Canada: The Special Case of Quebec." International Review of Education, 50(5): 543-566.

Gill, Hartej \& Graeme Chalmers. (2007). "Documenting Diversity: an Early Portrait of a Collaborative Teacher Education Initiative." International Journal of Inclusive Education, 11(5-6): 551-570.

Godlewska, Anne, Jackie Moore \& C. Drew Bednasek. (2010). "Cultivating Ignorance of Aboriginal Realities." Canadian Geographer, 54(4): 417-440.

Gollom, Mark \& Andrew Davidson. (2011). Harper: Majority Win Turns Page on Uncertainties. CBC News.

http://www.cbc.ca/news/politics/canadavotes2011/story/2011/05/02/cv-electionmain.html

Gomez, Mary Louise. (2007). "Seeing Our Lives Intertwined: Teacher Education for Cultural Inclusion." Language Arts, 84(4): 365-374.

Gonzales-Ramos, G \& Saches-Nester, M. (2001). "Responding to Immigrant Children's Mental Health Needs in the Schools: Project Mi Terra/My Country." Children and Schools, 23(1): 49-63.

Goodwin, A. Lin. (2002). "Teacher Preparation and the Education of Immigrant Children." Education and Urban Society, 34(156): 156-172.

Gosh, Ratna \& Norma Tarrow. (1993). "Multiculturalism and Teacher Educators: Views from Canada and the USA." Comparative Education, 29(1): 81-93.

Green, H. (1997). "May I Walk in Beauty." Guidance and Counseling, 12(2): 22-26.

Guevremont, Anne. (2010a). "The Early Learning Experiences of First Nations Children in Canada." Social and Aboriginal Statistics, Statistics Canada.

Guevremont, Anne. (2010b). "The Early Learning Experiences of Inuit Children in Canada." Social and Aboriginal Statistics, Statistics Canada.

Guevremont, Anne. (2010c). "The Early Learning Experiences of Metis Children in Canada." Social and Aboriginal Statistics, Statistics Canada. 
Hammond, V. L., P. J. Watson, B. J. O'Leary \& D. L. Cothnan. (2009). "Preliminary Assessment of Apache Hopefulness: Relationships with Hopefulness and with Collective as well as Personal Self-Esteem." Journal of the National Center, 16(3): 42-51.

Hammett, Robera \& Joyce Bainbridge. (2009). "Pre-service Teachers Explore Cultural Identity and Ideology through Picture Books." Literacy, 43(3): 152-159.

Heaven, Patrick \& Joseph Ciarrochi. (2008). "Parenting Styles, Gender and the Development of Hope and Self-Esteem." European Journal of Personality, 22(8): 707-724.

Henderson, Jennifer \& Pauline Wakeham. (2009). "Colonial Reckoning, National Reconciliation?: Aboriginal Peoples and the Culture of Redress in Canada." English Studies in Canada, 35(1): 1-26.

Henderson, Marion, Russel Ecob, Daniel Wright \& Charles Abraham. (2008). "What Explains Between-School Differences in Rates of Smoking?" BMC Public Health, 8: 218-233.

Hoerder, Dirk. (2006). ""Of Habits Subversive" or "Capable and Compassionate": Perceptions of Transpacific Migrants, 1850s-1940s." Canadian Ethnic Studies, $38(1): 1-22$.

Hunter, Boyd \& Kirrily Jordan. (2010). "Explaining Social Exclusion: Towards Social Inclusion for Indigenous Australians." Australian Journal of Social Issues, 45(2): 243-265.

Hutchinson, Charles B. (2009). "Introduction: The 'Minority Effect' as a Human Phenomenon and its Educational Implications." In Charles B. Hutchinson (Ed.), What Happens when Students are in the Minority: Experiences that Impact Human Performance (3-16). Lanham, Maryland: Rowman \& Littlefield Education.

Israel, Allen C. \& Masha Y. Ivanova. (2002). "Global Dimensional Self-Esteem in PreAdolescent and Early Adolescent Children who are Overweight: Age and Gender Difference." International Journal of Eating Disorders, 31(4): 424-429.

Lund, Darren. (2006). "Waking up the Neighbours: Surveying Multicultural and Antiracist Education in Canada, the United Kingdom, and the United States." Multicultural Perspectives, 8(1): 35-43.

Joshee, Reva \& Jeff Bullard. (1992). "Tension between Homogeneity and Diversity: Government Roles in Multicultural Education." Canadian Ethnic Studies, 24(3): 113-128. 
Kelley, Ninette \& Michael Trebilcock. (1998). The Making of the Mosaic: A History of Canadian Immigration Policy. Toronto: University of Toronto Press.

Kendzor, Darla E. Michael S. Businelle, Carlos A. Mazas, Ludmilla M. Cofta-Woerpel, Lorraine R. Reitzel, Jennifer Irvin Vidrine, Yisheng Li, Tracy J. Costello, Paul M. Cinciripini and Jasjit S. Ahluwalia. (2009). "Pathways between Socioeconomic Status and Modifiable Risk Factors among African American Smokers." Journal of Behavioral Medicine, 32(6): 545-557.

Kirova, Anna. (2008). "Critical and Emerging Discourses in Multicultural Education Literature: A Review." Canadian Ethnic Studies, 40(1): 101-124.

Kirova, Anna. (2001). "Social Isolation, Loneliness and Immigrant Students' Search for Belongingness: From Helplessness to Hopefulness." Paper presented at the Annual International Conference of the Association for Childhood Education. Toronto, Ontario.

Lawrence, Denis. (2006). Enhancing Self-Esteem in the Classroom. London: Paul Chapman Publishing.

Lund, Darren. (2003). "Educating for Social Justice: Making Sense of Multicultural and Antiracist Theory and Practice with Canadian Teacher Activists." Intercultural Education, 14(1): 3-16.

Lund, Darren. (2006). "Waking up the Neighbours: Surveying Multicultural and Antiracist Education in Canada, the United Kingdom, and the United States." Multicultural Perspectives, 8(1): 35-43.

McCann, Stewart J. H. (2010). "Subjective Well-Being, Personality, Demographic Variables and American State Differences in Smoking Prevalence." Nicotine and Tobacco Research, 12(9): 895-904.

Mujawamariya, Donatille. (2007). "Multicultural Education: Teacher Candidates Speak Out." In F. G. Johnson \& R. Enomoto. (Eds.), Race, Racialization, and Antiracism in Canada and Beyond (37-50). Toronto: University of Toronto Press.

Murray, Olivia. (2011). "A Call for K-12 Schools to Invest in Social Justice Education." Education Digest, 76(5): 60-64.

Nutbrown, Cathy \& Peter Clough. (2009). "Citizenship and Inclusion in the Early Years: Understanding and Responding to Children's Perspectives on Belonging." International Journal of Early Years and Migration, 17(3): 191-206. 
Moksnes, Unni K., Inger E. O. Moljord, Geir A. Espnes and D. G. Byrne. (2010). "The Association Between Stress and Emotional States in Adolescents: The Role of Gender and Self-Esteem." Personality and Individual Differences, 49(5): 430435.

Omidvar, Ratna \& Ted Richmond. (2003). "Immigrant Settlement and Social Inclusion in Canada." Toronto, Ontario: Laidlaw Foundation.

Peguero, Anthony A. \& Jennifer M. Bondy. (2010). "Immigration and Students' Relationship with Teachers." Education and Urban Society, 43(2): 165-183.

Perry, Laura \& Andrew McConney. (2010). "School Socio-Economic Composition and Student Outcomes in Australia: Implications for Education Policy." Australian Journal of Education, 54(1): 72-85.

Ramirez, Bruno. (2009). "Emigration from Canada to the United States in the Nineteenth and Twentieth Centuries." OAH Magazine of History, 23(4): 31-34.

Reitzel, Lorraine, Michael S. Businelle, Darla E. Kendzor, Yisheng Li, Yumei Cao, Yessenia Castro, Carlos A. Mazas, Ludmila Cofta-Woerpel, Paul M. Cinciripini \& David W. Wetter. (2010). "Subjective Social Status Predicts Long-Term Smoking Abstinence During Acute Withdrawal Through Effective Mediators." Addiction, 105(5): 928-936.

Rezai-Rashti, Goli. (2008). "Race, Text, and the Policies of Official Knowledge: A Critical Investigation of a Social Science Textbook in Ontario." Discourses: Studies in the Cultural Politics of Education, 29(4): 527-540.

Richards, John G., Aidan R. Vining \& David L. Weimer. (2010). “Aboriginal Performance on Standardized Tests: Evidence and Analysis from Provincial Schools in British Columbia." Policy Studies Journal, 38(1): 47-67.

Rousseau, C., A. Drapeau, L. Lacroix, D. Bagillshya and N. Heusch. (2005). "Evaluation of a Classroom Program of Creative Expression Workshops for Refugee and Immigrant Children." Journal of Child Psychology and Psychiatry, 46(2): 180185.

Rumbaugh Whitesell, Nancy, Christine M. Mitchell, C. E. Kaufman, P. Spicer and the Voices of Indian Teens Project Team. (2006). "Development Trajectories of Personal and Collective Self-Concept Among American Indian Adolescents." Child Development, 77(5): 1487-1503. 
Sabiston, Allison W., Chris Y. Lovato, Rashid Ahmed, Allison W. Pullman, Valerie Hadd, Sharon Campbell, Candace Mykforuk \& Stephen K. Brown. (2009).

"School Smoking Policy Characteristics and Individual Perceptions of the School

Tobacco Context: Are they Linked to Students' Smoking Status?" Journal of Youth and Adolescence, 38(10): 1374-1387.

Shebloski, B., Conger, K. J., \& Widaman, K. (2005). "Reciprocal links among differential parenting, perceived partiality, and self-worth: A three-wave longitudinal study." Journal of Family Psychology. Special issue: Sibling relationship contributions to individual and family well-being, 19: 633-642.

Spence, Nicholas, Jerry White \& Paul Maxim. (2007). "Modeling Educational Success of First Nations Students in Canada: Community Level Perspectives." Canadian Ethnic Studies, 39(1/2): 145-167.

Statistics Canada. (2009). "Immigration in Canada: A Portrait of the Foreign-Born Population, 2006 Census: Immigrants in the Provinces and Territories."

Stringhini, Silvia, Severina Sabia, Martin Skipley, Eric Brunner, Hermann Nabi, Mika Kirimaki and Archana Singh-Manoux. (2010). "Association of Socioeconomic Position with Health Behaviors and Mortality." Journal of the American Medical Association, 303(12): 1159-1166.

Tan, Eloise \& Haidee Smith Lefebre. (2010). "Tuning Frequencies of Multicultural Education Objectives to Distinct Society Perspectives: Two Teacher Candidate Interviews Transmitted through Narrative Inquiry." Intercultural Education, 21(4): 379-394.

Telzer, Eva H. (2011). "Expanding the Acculturative Gap-Distress Model: An Integrative Review of Research." Human Development, 53(6): 515-531.

Velund, Jarmund, Unni Medthassel \& Thormod Idsoe. (2009). "Perceived SocioEconomic Status and Social Inclusion in School: Interactions and Disadvantages." Scandinavian Journal of Educational Research, 53(6): 515-531.

Von Worde, Renee. (2003). "Students' Perspectives on Foreign Language Anxiety." Inquiry, 8(1): 1-15.

Welpy, Oscar. (2010). "Language Difference and Identity in Multicultural Classrooms: The Views of 'Immigrant-Background' Children in French and English Primary Schools." Compare, 40(3): 345-358.

Wotherspoon, Terry. (2002). "The Dynamics of Social Inclusion: Public Education and Aboriginal People in Canada." Toronto, Ontario: Laidlaw Foundation. 
Wright, Cynthia. (2003). "Moments of Emergence: Organizing By and With Undocumented and Non-Citizen People in Canada after September 11." Refuge, 2l(3): 5-15.

Young, Jon \& Robert J. Graham. (2000). "School and Curriculum Reform: Manitoba Frameworks \& Multicultural Teacher Education." Canadian Ethnic Studies, 32(1): 143-156.

"Youth Smoking Survey 2008-2009." (2010). Special Surveys Division. Ottawa, Statistics Canada. 